Article

\title{
Assessing Muslim Higher Education and Training Institutions (METIs) and Islamic Studies Provision in Universities in Britain: An Analysis of Training Provision for Muslim Religious Leadership after 9/11
}

\author{
Jawad Shah \\ Department of Arabic, Islamic and Middle Eastern Studies, University of Leeds, Leeds LS2 9JT, UK; \\ ml14j6s@leeds.ac.uk
}

Received: 22 October 2019; Accepted: 6 November 2019; Published: 11 November 2019

\begin{abstract}
The training of Imams and Muslim religious leaders has received much interest in the post-9/11 era, resulting in a vast amount of research and publications on the topic. The present work explores this literature with the aim of analysing key debates found therein. It finds that throughout the literature there is a pervasive demand for reform of the training and education provided by Muslim higher education and training institutions (METIs) and Islamic studies programmes at universities in the shape of a synthesis of the two pedagogic models. Such demands are founded on the claim that each is lacking in the appositeness of its provision apropos of the British Muslim population. This article calls for an alternative approach to the issue, namely, that the university and the METI each be accorded independence and freedom in its pedagogic ethos and practice (or else risk losing its identity), and a combined education from both instead be promoted as a holistic training model for Muslim religious leadership.
\end{abstract}

Keywords: Imam training; Muslim religious leadership; Islamic education; darul-ulums; Islamic studies; British Islam

\section{Introduction}

Few observers would disagree with the Orientalist Bernard Lewis' (1993, p. 263) assertion in his study of Islamic civilisations through the lens of Western Christendom that there is no church or church-like authority in Islam, and that instead the mantle of religious authority in Muslim communities is taken on by individual leadership, which, most visibly in the British context, includes the 'Imams' of the hundreds of mosques scattered throughout the country.

The term 'Imam' is an Arabic word translated by Wehr and Cowan (1993, p. 32) as literally 'guide' or 'leader'; it has been translated by some as 'in front of' (Mukadam and Scott-Baumann 2010), due to, it seems, their mistakenly assigning the diacritic fathah as the first vowel instead of the required kasrah. It has different connotations in Sunni and Shi'ite schools of Islam: Whilst for Sunnis 'Imam' is a title reserved for those who lead congregational prayers and occasionally extended to historically influential jurisconsults, for Shi'ites it is a rank of theological significance and an inherent component of their creedal postulations of prophecy and revelation (Scott-Baumann and Cheruvallil-Contractor 2015, pp. 57-81). However, the Sufi-oriented Barelvis from the Sunni school have also formulated a more complex spiritual hierarchy of Imam al-Kubra ('the greater Imam') and Imam al-Sughra ('the lesser Imam') (Geaves 2008, p. 108).

The roles of regular mosque Imams extend today beyond the traditionally limited confines of a number of congregational duties into 'professional managerial and pastoral' dimensions (Birt 2006). Consequent to this (and the ubiquitous inclination in the academic literature to draw 
Christian parallels) the term 'Imam' had become the de facto term for Muslim religious leadership in the nomenclature of this area of study (Scott-Baumann and Cheruvallil-Contractor 2015, p. 57). It is now being recognised, however, that there exists a whole plethora of platforms from which influence and authority may be exerted within Muslim communities (Mukadam and Scott-Baumann 2010; Scott-Baumann and Cheruvallil-Contractor 2015). There are firstly the ulama, a religious scholarly elite class, many of whom indeed are Imams themselves, and who are hailed by Qasim Zaman (2007) as the 'custodians of change' in Muslim societies. Alongside them are rival Muslim intellectuals mostly trained in universities, who may not have had the same traditional training of the ulama and are becoming a major source of consultation for the government on Muslim-related policy matters (Lewis and Hamid 2018, p. 51). Then there are charity workers, community organisers and campaigners, mosque management committee members, along with the incipient roles of chaplains and social media personalities (the latter of which arguably yield the most far-reaching followings in the digital media age) (Mukadam and Scott-Baumann 2010; Scott-Baumann and Cheruvallil-Contractor 2015).

These leaders, or 'religious professionals' as Sophie Gilliat-Ray (2006) prefers to label them, influence Muslim identity formation and socio-cultural thought, shaping the minds of Muslims of all ages; from children in the maktabs (local schools of religious learning), youth clubs, and on their electronic devices to adults attending Friday sermons, lectures, and counselling sessions. Given the extent of this influence, it should come as no surprise that these individuals, their training, and the institutions that provide the training are of much importance to government policymakers, academic researchers, and the British Muslim public alike.

Consequently, academic and policy research conducted thus far has resulted in the availability of a rich body of material, comprising government reports, academic literature, as well as a number of responses and innovative enterprises from within Muslim communities. Amongst the earliest studies into METIs are those conducted by Geaves, Philip Lewis, and Jonathan Birt, and these focus mainly on Deobandi institutions (Gilliat-Ray 2005, p. 8). Gilliat-Ray $(2005,2006)$, maybe driven by the inaccessibility of the Deobandi institutions, builds on these to produce a detailed and inclusive survey of institutions affiliated to other Muslim groups like the Shi'ites and the Azharis (linked to Al-Azhar University in Cairo). Following the Siddiqui Report, the government-commissioned Mukadam and Scott-Baumann Report was published in 2010, in which the different offerings of 'Muslim faith leadership' training were reviewed. On the other hand, works such as those of Alyaa Ebbiary (2018) and Lewis and Hamid (2018) focus on more recently established Muslim and Islamic 'colleges'. However, the earliest truly comprehensive 'insider' information on METIs comes from their graduates themselves; the likes of Hamid Mahmood (2012), Ebrahim Moosa (2015), and Haroon Sidat (2018), who were able to have much better access as 'insiders'.

This article, through a review of the literature on METIs and Islamic studies at universities, aims to explore and analyse key elements of the debate surrounding the training of Muslim religious leadership and the various forms of education systems available to them within the context of post-9/11 and post-7/7 Britain. It attempts to address the following three questions: (i) How valid are the most common criticisms levelled at shortcomings in the various forms of training provision for Muslim religious leadership in Britain? (ii) How have the institutions providing this training responded? (iii) And what is the effectiveness of the reforms proposed by the different stakeholders to improve it?

It finds that throughout the literature there persists a theme of criticising the inadequacy and incongruity of the training and education provided by METIs and universities for Muslim religious leadership within the British context and that coalescence of the two's pedagogical praxes is often proffered as the elementary characteristic of a comprehensive system. However, though this criticism may be applicable to a certain extent, it does not stand in its entirety as many METIs and universities continue to evolve in line with their environment. Moreover, the proposed reform via synthesis idea has proven ineffectual in several cases, largely due to the contrasting objectives of the two systems. Instead, I put forward an alternative proposal here to allow METIs and universities to push 
forward independently of one another, thus ensuring that they maintain their positive attributes and be able to rethink the shortcomings within their approaches at their own pace and with freedom from external ideological influences whilst also affording aspiring Muslim religious leaders the opportunities to benefit from a holistic training model that combines education from the two in lieu of a corrosive hybridisation.

\section{Terminology and Nomenclature}

\subsection{Defining the Training}

The training of Muslim religious leadership, just like its roles, takes various forms. To use Scott-Baumann and Cheruvallil-Contractor's (2015) 'twin-track system', it may be an education in Islam or about Islam, and in Britain this is currently provided at the highest level by METIs known as Darul-Ulums, Jamias, Hawzahs, and Muslim/Islamic 'colleges' on the one hand and by numerous mainstream universities on the other. From so-called 'faith-based' courses offered at METIs and 'academic', 'secular' ones offered at universities to language courses, online courses, and specialised vocational training for chaplains, there are a range of paths available to prospective Muslim religious leaders.

There is, resultantly, much debate about formulating a succinct terminology to define this training. Scott-Baumann and Cheruvallil-Contractor (2015), following Bernasek and Bunt (2010), attempt to contain the entire field under the label of 'Islamic studies', an 'umbrella term that encompasses a wide range of disciplinary approaches ranging from Islamic theology to sociology of Islam to Islamic finance and also a wide range of geographical areas'. They also reiterate the general assumption that the approach of METIs is a 'confessional' model of 'Classical Islamic Theology' distinct from the 'academic' courses of 'Islamic studies' at universities. Gilliat-Ray (2006, p. 64), in a somewhat nuanced expounding of this popular view, juxtaposes the 'academic rigour' of universities with the 'self-development' focus of METIs. A third binary is proffered by Mukadam and Scott-Baumann (2010, p. 44) that of 'Islamic sciences' in METIs and 'Islamic studies' in the universities. The scope and criteria of 'Islamic studies' at universities is then further debated with regard to whether it falls under religious studies, area or language studies, social sciences, or constitutes a separate discipline on its own - even whether it should be called 'Muslim Studies' instead (Scott-Baumann and Cheruvallil-Contractor 2015, pp. 9-56). During a meeting of leading academics with officials from the former Higher Education Funding Council England (HEFCE), it was concluded that the subject could be split across three areas, language-based studies, social sciences, and a core 'Islamic studies' based on traditional Muslim approaches of studying Islam (Higher Education Funding Council for England 2007). Sahin (2018), on the other hand, distances the Islamic studies courses found in universities, which he describes as 'a Western framing of the study of Islam that came out of the Eurocentric discourse of Orientalism', from a broader and more organic 'Islamic Education'.

Two dichotomous lines are being drawn between these forms of training: firstly, between the 'secular' and the 'religious', and, secondly, between the purely educational and the more pedagogic (in its original Greek meaning) or nurturing. However, as Lewis (1993, pp. 261-74) concludes, the imposition of the Western Christian concept of a secular-religious binary cannot fit well within a Muslim pedagogical framework for the simple reason that it does not carry over the same value in the Muslim imaginary, just as Asad's (2003) genealogical analysis highlights the contingency of this binary considering its historical conception and adoption in the early modern world of emerging European nation states. Therefore, despite the allure of comparing the two religions given all their parallels, constant comparisons between the two may actually present more problems than solutions given their distinct natures. Moreover, as Scott-Baumann and Cheruvallil-Contractor (2015, p. 24) later concede, in reality these lines of bifurcation are not as clearly defined as they are made out to be, especially with the continual changes many of the institutions are undergoing. Such a dichotomy also ignores the manqulat ('traditional sciences')/ma'qulat ('rational sciences') binary, the two halves making up 
the whole that is Islamic learning and paramount to the classical tradition of METIs (Geaves 2008; Mahmood 2012, pp. 12-13).

\subsection{Problematic Terminology: Darul-Ulum and the Seminary}

As argued earlier, METIs have for some time remained largely understudied and they are, therefore, frequently misunderstood. They are often incorrectly linked to unrelated developments in the Muslim world, such as the Taliban movement or Jihadist groups like al-Qaeda and ISIS, and have been branded with pejorative labels such as 'Jihad Factories' (Hefner and Zaman 2007; Birt 2006). Moreover, the default term for METIs in Britain usually is 'Darul-Ulum', defined by Birt and Lewis (2010, p. 93) as 'ulama-led educational institutions training students in the traditional Islamic sciences', for which the English equivalent presented is 'seminary' (Gilliat-Ray 2005). However, in continuing to question the Christian-influenced nomenclature of this area of study, the selection of both terms is questionable.

Firstly, the term 'Darul-Ulum' is associated mostly with Deobandi institutions and, therefore, its use as the term of choice disregards other significant Muslim currents in the country that prefer alternative designations for their own institutions: such as the Barelvi 'Jamias', Shi'ite 'Hawzahs', and METIs that adopt the titles of 'college' or 'institute' (like the Deobandi Ebrahim College or the Markfield Institute) (Scott-Baumann and Cheruvallil-Contractor 2015, p. 35). This also ignores the existence of many informal learning centres providing the same education (Birt and Lewis 2010, p. 93; Geaves 2008, p. 108). Admitted, the largest portion of METIs in Britain are Deobandi-affiliated (approximately 70\%) (Mahmood 2012, p. 50), whilst South Asians make up most of the British Muslim population (around 66\%), which is also reflected in the religious leadership (South Asian Imams made up $83.7 \%$ in the results of a 2008 survey) (Geaves 2008, p. 102); nevertheless, describing these institutions solely through a Deobandi (or even a South Asian) frame of reference will result in the promulgation of views that ironically overlook minority voices and the nuanced ways that British Muslims have gone about disseminating knowledge.

One alternative adopted by writers such as Peter Mandaville (2006), Mahmood (2012), Moosa (2015), and Sidat (2018) is the term 'Madrasah'. Another, chosen by Scott-Baumann and Cheruvallil-Contractor (2015), is the expression 'Muslim institution'. The latter evidently seems like the more suitable choice in this case, avoiding the possibility of mistranslation and adequately covering the broad range of approaches; however, it is too generic to provide the specificity required for the present discussion, so I propose it be qualified further to 'Muslim Higher Education and Training Institutions' (or METIs for short), incorporating both the pedagogic and the vocational provisions of these institutions.

Secondly, 'seminary' as a translation (for darul-ulum or its cognates in Britain) is also problematic as in its original context 'seminary' implies a provision of training solely for religious leadership (Scott-Baumann and Cheruvallil-Contractor 2015, p. 42), which as we shall see in the coming discussion is neither the sole nor principal aim of METIs. This term too is borrowed from a Christian lexicon, emblematic of the perpetual urge to force Western Christian terms on to Islamic cognates that is so prevalent in this field.

\section{Criticisms of the Training}

\subsection{Criticism of METIs}

Throughout the literature, the main criticism brought against METIs is their importation of foreign contexts, resulting in outdated curricula that are irrelevant to British Muslims and communicated to them in a foreign language. Siddiqui says that for the most part these institutions are 'oblivious of the realities around them', while a report from the Muslim Council of Britain deemed their system of education to be 'inadequate' with 'serious shortcomings' (Siddiqui 2007; Mukadam and Scott-Baumann 2010). Musharraf Hussain, himself the director of a METI, asserts that graduates from 'Islamic seminaries' are 
'without sufficient communication skills [ ... ] leadership skills, and without a good understanding of British culture' (Mukadam and Scott-Baumann 2010, p. 9).

The argument is that many British Deobandi and Barelvi institutions remain stuck within their original Indian milieus, relying on a curriculum known as the Dars-e-Nizami, conceived of in pre-colonial India and further developed in the nation's colonial period (Mahmood 2012), and that even today, despite the demand for English-speaking leaders, their language of instruction is usually in Urdu (Lewis and Hamid 2018, pp. 47-48), meaning that even whilst having mastery of English, the conveyance to an English audience of subject matter they had received in Urdu can be difficult for METI graduates. From Geaves' (2008, pp. 107-10), Mahmood's (2012), and Sidat's (2018) work, it becomes evident that even amongst the graduates of these METIs there is some discontent. Mahmood (2012) contends that the Dars-e-Nizami model is imported wholesale from the subcontinent, where it had been formerly transplanted from the Arab world in the aftermath of the sacking of Baghdad in 1258 . He argues that following the uprising against the British Raj in 1857, the approach of some Muslims changed from open reform to preservation, and this along with the resultant stagnation of scholarship carried over into the British context.

Not all METIs are following these trends though. For example, Geaves (2008) demonstrates how Barelvis see too much of a change from their original context in their institutions and would prefer a return to an emphasised spirituality through the shaykh-murid relationship. Gilliat-Ray (2006) touches on the contextualised focus of the Shi'ite and Azhari 'colleges', which are seen to represent the continuous adaptations of METIs to changing contexts, with some of them even awarding accredited degrees. ${ }^{1}$ Furthermore, as Mukadam and Scott-Baumann's (2010, p. 41) report shows, most of the Deobandi darul-ulums too have made several changes to their syllabi to conform to their current environment, and as Sidat (2018, p. 5) insists as well, with the emergence of British-born teachers has come the increasing adoption of English as the language of instruction.

Another major point of concern raised by several authors is that of the opportunities available to the graduates of METIs. The concern is that, with unrecognised qualifications, the only career option for most graduates is to serve as Imams in mosques, but, as Birt and Lewis (2010) highlight, there are too few mosques to accommodate them all, leaving a surplus of graduates looking for work. However, from the existing research, it becomes clear that a future career in Muslim religious leadership is not always the primary motivation for studying at METIs, nor the leading factor in student recruitment. Some parents send their children solely for a Muslim upbringing and education-to make them 'better Muslims' - and see this as a way to ensure the child's protection in adolescence from culture parents perceive as immoral (Scott-Baumann and Cheruvallil-Contractor 2015, p. 37; Gilliat-Ray 2006, p. 68). Ebbiary (2018, p. 332) says the training in METIs is not designed to produce qualified Imams, but rather trainee scholars. It is even suggested that poorer families, as it is the case in the Subcontinent, see these institutions as a place where their children can be 'housed and fed for eleven months of the year for a relatively small cost (Gilliat-Ray 2006, p. 68.). The developing individuation process highlighted by Geaves (2008, p. 108), where older students, influenced by global preachers, seek a religious education as part of their 'reversion', also shows that this form of study is not merely career-oriented. This would mean that, just as Moosa (2015, p. 53) found to be the case in India, not all graduates of British METIs would be contemplating a full-time imamate or teaching position, and would simply aim to apply their knowledge and moral training in their daily lives. The primary purpose of such institutions, therefore, is to cultivate piety and instil religious values in their students, referred to in the literature as a 'self-development focus' (Gilliat-Ray 2006), 'Taqlid-e-Shakhsi' (Mahmood 2012), an 'otherworldly trend' (Moosa 2015), and a 'tarbiyyatic pedagogy' (Sidat 2018).

1 These too can perhaps be better understood in light of their original contexts, e.g., the strong presence of the rational sciences in Persia/Iran, or the Wahhabi and Nahda movements in the Arab world. 
Furthermore, this employability issue would not be an issue for the degree-awarding Islamic/Muslim colleges, though as Gilliat-Ray (2006, p. 63) asserts (in reference to the Muslim College) few students of these colleges go on to become imams. The Shi'ite models are not explored as much in this regard, the results of which would be interesting given their unique structures of religious leadership. On the other hand, although there are fewer female-only or co-educational METIs than male-only ones (six female-only METIs offering a complete Alimah course were identified in the Mukadam and Scott-Baumann Report (2010, pp. 40, 71-73), whose student numbers totalled to 1606), because of their larger intake the total number of female students at METIs is almost equal to the number of male students; and so it would be easy to assume that the generally underresearched female graduates of METIs have the worst prospects in terms of employment opportunities for religious leadership roles. There is indeed a commonly held notion that females cannot become Imams, and it has been identified that the leading roles in fields such as teaching at many METIs are held by men (Scott-Baumann and Cheruvallil-Contractor 2015, pp. 121-22); however, more and more Muslim women are challenging these norms by adopting various roles of religious leadership within their communities. There have been several recent examples of female Imams leading congregations (Lewis and Hamid 2018; Petersen 2019); a rising number of Muslim women taking up chaplaincies, where they even have certain advantages over their male counterparts (Gilliat-Ray et al. 2013); and an emerging cadre of female METI graduates realising that they provide unique services of 'personal and collective guidance' to their communities that tend to override the need for conspicuous career paths but nevertheless propel these women forward as authorities within a male-dominated space (Liberatore 2019). Nevertheless, further research is required on the experiences of female alumni of METIs to uncover the extent to which gendered dynamics influence their subsequent career trajectories.

There are several reasons presented for the lack of, or the slow rate of, progress in METIs. Mahmood (2012, p. 45) states that hurdles tend to arise from older members, who, having grown up in the original homeland context, are most inclined to preserve it undiluted. Sidat (2018, p. 9), likewise, points to senior teachers and their eagerness to imitate their 'akaabir (pious ancestors)'. Mainly though, it is the isolationist tendencies of movements like the Deobandis that are blamed for creating closed-off worlds, meaning that even the new generation of graduates, from whom the most is expected, can end up paradoxically entering mainstream society with their institutionalised, inward-looking weltanschauung (Gilliat-Ray 2006, p. 71). Lewis and Hamid (2018, p. 28) uncover another potential barrier to change in the form of the 'first generation in every generation' phenomenon prevalent amongst some British Muslim communities due to a large percentage of marriages arranged with partners from abroad, meaning that foreign contexts cannot be entirely eliminated and will be renewed in every generation. One further reason is the security-oriented approach of the government towards METIs, which can sabotage the prospects for positive co-operation, even though, as recognised by those who have studied them, these institutions are part of the solution and not the problem (Birt and Lewis 2010; Birt 2006, 2016).

Nevertheless, as most of the research interviews conducted with British Muslims (Siddiqui 2007)—and Moosa's (2015, p. 241) personal admission—make plain, the teaching offered by METIs is still held to be the most 'authentic' and, therefore, cannot be disregarded. If indeed their twin aims are to preserve their heritage and culture and to engage solely or primarily in a 'tarbiyyatic pedagogy', then they can be said to have been highly successful in achieving these aims so far, and, notwithstanding the aforementioned criticisms, there is a general acceptance that these institutions have indeed evolved somewhat with time and continue to adapt slowly at their own pace to their new context.

Moreover, it is never spelt out in detail in the literature what the required rate of 'progress' is supposed to be; nor indeed if this demand for reform falls under the perpetual promulgation of Western

2 Sidat agrees that akaabir may be better translated as 'great elders' in line with Ingram (2018) translation. 
liberalism via a modus operandi resembling a neo-colonial imaginary highlighted by authors such as Joseph Massad (2016), or what Sayyid and Hesse (2006) refer to as the attempted 'assimilation' of the 'ex-colonial ethnically-marked "immigrant"'.

\subsection{Criticism of Universities}

The pressing question in this context about the teaching of Islam in universities is whether or not this would be recognised by the Muslim community as 'legitimate' training for Muslim religious leadership. It seems that the majority of Muslims do not see the study of Islam at a university as sufficient; as the Siddiqui (2007) shows, they would rather go to a METI for that, and, as Geaves (2008, p. 110) notes, 'an Imam trained outside the darul-ulums and without the dars-i-nizami would not be accepted' in their communities. There is also a suspicion of Islamic studies taught in Western universities on the basis of Orientalist biases and hidden agendas (Moosa 2015, pp. 52-53; Larsson 2018, p. 130), evinced in public comments shared on sites like Youtube from globally influential Muslim scholars such as Noman Ali Khan and Yasir Qadhi (whose influence amongst British Muslims is recognised in Geaves' (2008, p. 108) work), which dissuades Muslim students from joining these courses. However, this may well be changing now, for although criticism of Orientalism in Western universities may have been well-founded in previous decades, a growing number of the leading lecturers in these departments are now Muslim scholars, and the numbers of Muslim students taking up these courses are also increasing; whilst there can also generally be seen efforts to decolonise the curriculum (Suleiman and Shihadeh 2007).

The second critique of the universities' provision of Islamic studies almost mirrors that of METIs; that is, a criticism is made of their decontexualised focus on the Arab and Middle Eastern world-and on texts instead of communities. Sources of this bias are said to be the aftereffects of the colonial legacy and Orientalism at a state level, and little to no engagement with local Muslim communities on the local level (Higher Education Funding Council for England 2007, pp. 8-10; Siddiqui 2007). The discussions the HEFCE had with academics, as well as the Siddiqui Report which they were driven by, both highlight the deficient study of South Asian Islam in these degree programmes, a shade of Islam that represents its largest demographic component in Britain and not only the origin of most British Muslims but also of most of the students enrolled on these courses too (the complete non-existence of a study of minority South Asian Muslim cultures such as the Pashtuns makes for a striking example of this issue) (Higher Education Funding Council for England 2007, 2008a; Siddiqui 2007, pp. 23-24). In these discussions, leading British academics of the field, Shuruq Naguib and Hugh Goddard, expressed the need to include the study of Islam in communities outside the Arab world and of what Naguib terms 'living Islam' (Higher Education Funding Council for England 2007, pp. 8-12). Moreover, although the Arabic language features centrally in most university courses-as Robert Gleave (Higher Education Funding Council for England 2007, pp. 6-8) argues it should-Urdu, the language of much South Asian Islamic literature and arguably as prominent a language of Islamic learning as Persian or Turkish, unfortunately remains neglected (Higher Education Funding Council for England 2007). Indeed, as important as the current focus of universities on Arabic is, given its obvious indispensability in any serious study of the formation of Islamic civilisation, there should be due weight given to post-formative iterations of Islam, especially those that are also relevant to the British and wider Western context.

Finally, there is the overarching dilemma of maintaining the 'secular' ethos of the university when it comes to the study of religion -if indeed Islam can be said to be a 'religion' in the Western sense of the word, as it can be argued that it is perhaps coming to be seen as more of a culture or ethnicity in its diasporic form. Can it remain purely academic - or from the point of view of many prospective Muslim students, should it? Goran Larsson (2018) concludes that subjects such as Islamic theology (and all types of theology for that matter), even if they are labelled as 'academic', do not belong in today's Western universities; especially given that, according to him, most Muslim students only choose this subject for faith reasons. Moreover, he cites the argument of Donald Wiebe that academic disciplines in 
this area should not be utilised to achieve religious, cultural, or political goals (Larsson 2018)—-though we should remain wary of uncritically applying the context of other European countries to Britain's own idiosyncratic setting. Likewise, Aaron Hughes (2008) avers that the university study of Islam should not comprise a 'colour commentary' on Muslim life and practice, but rather the focus should be exploring Islam as a social construct in line with the broader framework of Religious Studies.

This assumption about the incompatibility of the two systems is a pervasive one as Scott-Baumann and Cheruvallil-Contractor (2015, p. 146) show, pointing towards fears of 'religious students' on 'secular campuses'. However, the veracity of such an assumption may be called into question: Geaves (2013) finds in his research that the differences in pedagogy between the two systems are often overplayed, whilst Sahin (2018) also demonstrates the errors of such a binary. Similarly, Asad's (2003) work expounds upon the complexities of the notion of 'secular' in relation to 'religious' as well as the various historical overlaps between the two. Scott-Baumann and Cheruvallil-Contractor (2015, p. 144) continue to argue that the need for a 'confessional religious education' is for religious leadership in all faiths in pluralist Europe. Siddiqui (2007) too contends that universities have a faith element to them in terms of the religious plurality of their audiences and should cater to this niche.

On the whole, universities too, like METIs, are adapting to changing contexts with a number of collaborations with local Muslim communities and METIs (to be discussed in the next section) as well as the growing inclusion of Muslim academics who can and will change the topography of the field-although as we are currently in the early stages of this paradigm shift it would be premature to assume how far and in what ways this will happen, given that there is already some opposition to what is perceived as a developing Muslim apologist approach in the academic study of Islam post-9/11 (Hughes 2008). The 'Re/presenting Islam on Campus' project headed by Scott-Baumann et al. can be cited as a positive effort in this regard, which will no doubt help in understanding further the relationship between the university and its faith-oriented constituents. ${ }^{3}$ Muslim women are also helped by university programmes, and though their numbers may be low relative to male staff in the teaching positions (Suleiman and Shihadeh 2007), they take up the larger portion of places on undergraduate courses (Higher Education Funding Council for England 2008b) in an experience that is life-changing for them and allows them to rethink the postulates of their tradition in line with their intersectional identities (Scott-Baumann and Cheruvallil-Contractor 2015; Tyrer and Ahmad 2006). Moreover, several graduates of METIs take up study at universities, many of whom go on to bring about positive change in their communities and from whom much is expected (Lewis and Hamid 2018; Birt and Lewis 2010).

\section{Changing Circumstances and Reform}

\subsection{METIs and Reform}

Over the centuries, one of the enduring characteristics of the Islamic civilisation has been the proliferation of its variant localised currents as it acquired local flavour with its geographical spread. The heterogeneity of METIs all over the world is exemplified in Hefner and Zaman's (2007) work, showing how they reflect their localised contexts and are constantly evolving and dealing with change in their own manner. A look into the past shows that internal debate about Muslim pedagogy was rife from the very outset during the formation of these institutions; and ever since there have existed figures who seek to rethink the epistemological and pedagogical frameworks of Muslim societies- the critical and reformist views of some of the early Deobandi ulama being a case in point (Geaves 2008, pp. 106-7; Reetz 2010, pp. 111-22; Mahmood 2012, pp. 42-48; Moosa 2015, p. 47; Sidat 2018, p. 5).

As mentioned earlier, in Britain too, METIs have been updating their systems of education in line with their new context. Many METIs teach core subjects of the National Curriculum (for 
which a large number of them enjoy positive Ofsted reports) with the provision of GCSEs and A-levels as well as BTEC qualifications, thereby opening up the possibility for the re-integration of the ma'qulat element of their original curricula (Mukadam and Scott-Baumann 2010, pp. 42-43; Geaves 2008, p. 111). These curricula have been updated, with English becoming a more common language of instruction, and several young teachers are adopting modern methods of teaching (Geaves 2013, pp. 8-10; Mukadam and Scott-Baumann 2010, p. 41). Of the reasons cited as causes for this change, chief is the emergence of a new generation with different needs and priorities to its elders and which, through seeking employment or further study, sees the inefficacy of its schooling, initiating an internal shift from a migrant-outlook to a citizen-outlook (Mahmood 2012, p. 45; Sidat 2018, pp. 5, 11; Gilliat-Ray 2018).

These changes by METIs represent their own individual and autonomous attempts to rethink their positions in light of the demands of their ever-changing worlds and may indeed be interpreted as expressions of their own modernities - and they should not be disregarded as inadequate on the basis of a Western modernity as the sole standard through which progress can be measured and assessed. As Hefner and Zaman (2007) reminds us, citing the Israeli sociologist Shmuel Eisenstadt, 'modernity is multiple, not singular' and as Mignolo (2009) remonstrates, Western ideas of modernity-shown by Asad (2003) as commonly perceived to be linked with the centralisation of the 'secular'-should not dictate the waves of global change by ignoring 'alternative modernities'.

\subsection{Muslim Colleges: Blurring the Lines of Division}

Amongst METIs in Britain, the 'colleges' are seen as the perfect 'hybrid institutions', reuniting the 'sacred' and 'secular' sciences of the classical Muslim tradition (Ebbiary 2018). If their Darul-Ulum counterparts represent the reactionary split of their tradition's 'sacred' elements in opposition to the dominant 'secular' education system, then these 'colleges', formed afresh in this new context, represent attempts to bring the two back together once more-though each institution varies in its approach.

Although the more traditional METIs (traditional in the sense of opting to prioritise, at least ostensibly, the transmission and preservation of their curricula and pedagogy instead of major reforms of these) and universities have also responded to the demands of the British context, neither can seem to do so as freely as these 'colleges' perhaps due partly to their desire to maintain their original ethos and identities. This is not an issue for METIs adopting the relatively more flexible labels of 'college' or 'institute', which can as a result be more freely situated on the pedagogical spectrum (in between the traditional METI and the university). Evidence of this comes from the fact that in their 2010 report, Bernasek and Bunt (2010, p. 26) listed four of these colleges as offering validated modules and degrees: Al-Maktoum Institute (which was accredited by the University of Aberdeen but no longer exists), the Shi'ite Islamic College (accredited by Middlesex University), Markfield Institute-where Abdullah Sahin has developed the first MEd in Islamic Education (accredited by Newman University and prior to this by the University of Gloucestershire), and the Muslim College (previously accredited by Birkbeck College and now by ASIC). The Cambridge Muslim College has recently managed to obtain validation from the Open University for its BA in Islamic Studies programme; the Al-Mahdi Institute has established a partnership with the University of Birmingham where final year students of its Hawzah programme can receive an MA in Islamic Studies; whilst Ebrahim College has also been working towards developing validated courses, with already existing extensive collaborations with universities and other institutes (Lewis and Hamid 2018, pp. 56-58; Ebbiary 2018). More recent establishments of such institutions include the Cambridge Islamic College and, the first of its kind in the north, the Bradford Muslim College.

Furthermore, these colleges are able to break with cultural norms and allow mixed-gender classes, promote an open door policy untypical of traditional METIs, and employ non-Muslim lecturers on their staff; in addition, they offer more practical vocational training for chaplains and imams, which, as Ali argues, will help curb the pastoral 'liminality' of current Imams given the discharge of pastoral dimensions now expected in their roles (Ebbiary 2018; Ali 2018). Another feature of such 
institutes is the further opening of opportunities for female religious leaders, who can find through these courses alternative careers in chaplaincy, higher education, and so on (Scott-Baumann and Cheruvallil-Contractor 2015, pp. 128-30). Most of the female scholars mentioned in Liberatore's (2019) work for example had studied at Muslim colleges.

\subsection{Universities and Reform}

Universities also seem to show some interest in rethinking their strategies to include collaboration with METIs (Suleiman and Shihadeh 2007, p. 317; Bernasek and Bunt 2008). There have been a number of these, which include-in addition to the ones mentioned above; the University of Winchester with the Khoja Shiite Ithna-Asheri Community's Islamic Institute for Postgraduate Studies in Damascus, Lampeter University with the European Institute of Human Sciences (EIHS), and the University of Cambridge with the Azhar University (as well as with Cambridge Muslim College on an informal basis) (Mukadam and Scott-Baumann 2010, pp. 44-47; Geaves 2013, p. 3). A lasting positive and successful example is the partnership between the University of Middlesex and The Islamic College, which, with its mixture of validated and non-validated modules, could be an efficacious blueprint for other Muslim 'colleges'; whilst a more recent one between MIHE and Newman University also shows promise (Scott-Baumann and Cheruvallil-Contractor 2015, pp. 136-38). The University of Leeds created a certificate course in Islamic Studies as a result of interactions with the local Muslim community (especially women), and has also facilitated the establishment of the nascent 'Iqbal Centre for the Study of Contemporary Islam' (Siddiqui 2007, Appendix D).

\subsection{Bringing the Two Together}

The most ubiquitous calls for reform in the training provision of Muslim religious leadership put forward the demand that as two distinct educational systems, each lacking full capacity on its own, METIs and universities should work together in a complementary fashion. Both would need to update their curricula, whilst universities are charged with 'connecting' to local METIs and assisting them in acquiring accreditation. Analysing the conception of the Dars-e-Nizami as an elite curriculum in Mughal India, several authors point to how it was updated and developed for a specific context much different to that of modern-day Britain, and how the same should be done today by its adherents in the British context (Geaves 2008, pp. 105-7; Birt and Lewis 2010, p. 117; Mahmood 2012, pp. 42-45; Moosa 2015).

The effectiveness of such reform proposals, however, remains to be seen. A major obstacle arises in the form of the numerous METIs that take on students at a younger age (38 such institutions were listed in the Mukadam and Scott-Baumann 2010), where almost all of the curriculum is completed alongside Levels 1-3 of the National Qualifications Framework. It was in response to this problem that this report recommended that the syllabus of METIs be aligned with the NQF, with recognised qualifications to accommodate all levels (1-6) of instruction (Mukadam and Scott-Baumann 2010, pp. 67-68). Nevertheless, as Sahin (2018, p. 3) shows, such initiatives can only be properly formulated and carried out by specialist Education Studies experts who would ideally have experienced both educational systems, but at present such expertise is short in supply. 4

Furthermore, despite a few successful ventures alluded to here, it looks as though there is an impassable barrier prohibiting collaboration. An irreconcilable, and almost civilizational, clash persists between the two systems: The universities' offering is not legitimate in the eyes of Muslims, whereas

4 However, as Gleave (Higher Education Funding Council for England 2007, pp. 6-8) contends in his rejoinder to the Siddiqui report, this would mean complying unwillingly with the demand that Muslim lecturers should teach modules on Islam, as they are the only ones able to access both the 'traditional' METIs and universities, and would result in a recruitment bias; although it may be noted that this issue would easily be resolved now with the many colleges and institutes offering an 'insider perspective' to students from all backgrounds. 
the 'faith-based' curriculum of METIs is not in line with the quality assurance standards of universities (Siddiqui 2007, p. 31; Scott-Baumann and Cheruvallil-Contractor 2015, pp. 133-58). Two of the four partnerships noted by Bernasek and Bunt proved short-lived, and there has been to date no successful collaboration with any British Deobandi darul-ulum (Scott-Baumann and Cheruvallil-Contractor 2015, p. 138; Geaves 2013). ${ }^{5}$

Moreover, it is apparent that whilst METIs are keen to make these collaborations (perhaps because they stand to benefit more immediately in the form of validated courses), universities do not share the same enthusiasm. Scott-Baumann and Cheruvallil-Contractor (2015, pp. 147-48, 157) note several refusals from universities to set up partnerships with METIs between 1998 and 2015, whilst their ESRC-funded project in 2013 exploring collaborative partnerships between METIs and universities saw limited university uptake in comparison to the representation from METIs. Both Siddiqui (2007) and Mukadam and Scott-Baumann (2010) highlight the willingness of METIs to work with universities in order to seek accreditation. Geaves' (2013, pp. 8-12) darul-ulum project discovered that institutions from Blackburn and Bolton had already made attempts to set up partnerships with local universities, and even went so far as to provide alternative facilities to host the courses-in an attempt to placate concerns over 'permitting post-puberty males to travel alone into gender-mixed FE/HE environments'. However, it is important to clarify that this is not the case with all METIs, who in no way form a monolithic bloc, for, as Geaves' (2013) demonstrates and Mahmood (2012, p. 16) emphasises, the Deobandi darul-ulums differ amongst themselves on the merits of HE collaboration-the Deobandi 'mother institute' in Bury being a prime example of some METIs' disinterest in the idea of partnership (though as Birt and Lewis (2010, p. 100) show, Darul-Ulum Bury was bringing about changes in its own way, encouraging its graduates to take up further study at universities).

The main issue for such collaborations, claim Scott-Baumann and Cheruvallil-Contractor (2015, pp. 140-41), arises from the significant amounts of funding required by both types of institutions. Furthermore, they show that changing approaches in today's universities, inclined towards a 'neoliberal managerialism', push the focus towards the economic value of their programmes instead. ${ }^{6}$ There is also the ever-present spectre of Islamophobia and prejudiced counter-terrorism agendas that can inhibit co-operation from both sides, especially with the prevalent suspicions of a link between university campuses and radicalisation (Scott-Baumann and Cheruvallil-Contractor 2015, p. 152; Department for Education and Skills 2006).

The question also remains as to what the ultimate end product would be of such collaborations if they prove successful, for as Scott-Baumann and Cheruvallil-Contractor (2015, p. 141) illustrate, each institution will of course try to influence the other, though the validating university will have the upper hand. In that case, would the university swallow the METI completely, as an affiliate body under its authority or even as a fully-integrated department? Both scenarios would force METIs to shed much of their original identities, which surely cannot be the desired outcome for them given that they are all almost exclusively formed on the basis of a distinct Muslim intellectual heritage, pedagogy and ethical formation, which should retain paradigmatic status under conditions of change rather than face assimilation into the secular British HE system.

\subsection{Alternative Possibilities}

It becomes clear that METIs are important centres of authoritative religious learning for many Muslims, providing education that universities do not (and arguably should not) offer. As seen from the literature, the dominant view amongst Muslim students is that only Muslim teachers in METIs can properly communicate the spiritual and confessional elements of their faith. So perhaps such a

5 Professor Geaves was contacted during the research for this essay, and he explained how his efforts in this project to set up partnerships for two Deobandi Darul-Ulums in North West England eventually turned out to be unsuccessful.

6 The importance of funding for private METIs was also expressed in the 'Islam on Campus' report (Suleiman and Shihadeh 2007, pp. 322-24). 
syncretism of the METI and university models is not fitting if it would significantly disrupt, perhaps even fatally, the continued healthy transmission of traditional religious values through the maintenance of viable independent ulama-led educational institutions. It is for this reason that even METIs that have moved away from the traditional system are seen by Michael Mumisa (2014) as struggling with a 'crisis of identity' (referring to 'modern Islamic colleges'); so even if they are described as successful 'hybrid' models by some academics as highlighted earlier, they are not always held in the same positive light by Muslims (Geaves 2008; Gilliat-Ray 2006).

Therefore, instead of trying to fuse together the idiosyncratic worlds of the METI and the university, perhaps it would be better to keep them apart, empowering each to traverse its own trajectory independently and adapt its own pedagogical style over time, and to evolve in its own natural way and at its own pace. This can primarily be achieved if no institution is required to be entirely dependent on another (in most cases the METI on the university) for validation or accreditation, which is where Mukadam and Scott-Baumann (2010) proposals can play a key role in granting METIs their independence. Both approaches, the university and the METI, like the two sides of a coin, are crucial in creating traditionally trained scholars conversant with contemporary realities and therefore must be kept separate-at least for the moment. Moreover, Muslim students of sacred knowledge should be encouraged to study at both in order to benefit from the positives of each, gaining both the 'insider' and 'outsider' perspective to balance the biases of each, whilst also benefitting from Muslim lecturers who have studied under both systems (and are found in both systems too-such as Dr Ibrahim Harvey at Ebrahim College) and present a unique syncretic approach. ${ }^{7}$ However, some level of co-operation should be maintained between METIs and universities through the exchange of ideas and a fluid transfer of students as in the Leeds example, which will promote better awareness, development, and community cohesion.

This approach of integrating the two systems as part of a holistic model of training instead of synthesising them could help in creating a generation of much-needed experts who can develop this field theoretically and internally formulate the most appropriate models for these institutions going forward. Moreover, this would reflect recent positive trends in the field's research methods where Muslim and non-Muslim academics combine to paint a more balanced picture through presenting both 'insider' and 'outsider' perspectives. Lewis and Hamid (2018, pp. 47-90), whose work is an example of this collaboration, have shown in their case studies of two METI graduates the positive results of combined perspectives.

Admittedly, the synthesised Muslim colleges pose a conundrum for such a proposal in that they seem to be the inevitable result of such a twin education; however, the more successful ones amongst them, such as the Shi'ite colleges mentioned earlier, have incorporated more of a combination of the two systems rather than a complete synthesis, and these can, therefore, serve as unique models for similar institutions to follow.

\section{Conclusions}

The resounding impression that becomes apparent from the literature reviewed in the foregoing discussion is that the training of Muslim religious leadership in Britain is in need of further improvement; at either ends of the spectrum, the offerings of the METI and the university are both inadequate, and a blend of the two is what is ultimately required. Though different parties prioritise different demands, the overall insistence is essentially for this training to reflect both intersectional layers of British Muslim identities, the British and the Muslim—which, it is argued, the current provision does not do.

7 The concepts of the 'insider' and the 'outsider' are vague, with undefined boundaries and several overlaps; they are used here solely for lack of better terms. With the 'insider' view there will be the difficulty to detach oneself from something as dear to them as their faith, but on the other hand this could also be over-compensated for in order to appear impartial. Likewise, 'outsiders' may have a negative or suspicious view of a subject that they cannot be as well-informed about, but may also be inclined to compensate for their 'outsiderness' by a bias in favour of their subjects of study. 
However, this essay concludes that whilst this criticism may be well-founded, the METIs and the universities have both indeed responded internally to their changing contexts in their own ways, and the proposed reform of conflating the two systems is not the most felicitous and may be described as an attempt at cultural assimilation. Questions remain about the effectiveness of the suggested reform proposals given their many failures, whilst the generally implicit motives of the university-based academics pushing for reform, who may be unwittingly (or even wittingly) seeking to impress their own Western liberal ideas on entirely dissimilar systems, also need to be scrutinised. Furthermore, there is ironically a discriminatory focus on the Deobandi and South Asian METIs, with an unequal exploration of other groups such as the Barelvis and the Shi'ites, the influx of Salafist views through the internet, or even female METIs. Overall, it can be seen that this area of study is in need of much formulation at the theoretical level, perhaps because it has not yet had enough time and opportunities to develop.

The alternative recommendation proffered here is that instead of continuing conceivably futile attempts at a synthesis of two disparate systems, the provision of the METIs and the universities should be kept separate and each should be integrated individually into Muslim Religious Leadership training instead, thus keeping in line with the aforementioned necessity of respecting their differences and not imposing (upon either) foreign and unrelatable notions. Originating from divergent contexts, they obviously have differing raisons d'être that grants them their identities, and each offers unique benefits that the other cannot provide, but a fusion of the two would ultimately force them to water these down or abandon them.

The best-case scenario would be every institution functioning independently and freely according to its own ideals. For this to come to fruition though the METIs would require a system of validation for their provision that does not mean relying on another institution, and here the recommendations of Mukadam and Scott-Baumann should be developed and utilised. Subsequently, in order to gain a holistic training, Muslim religious leadership would be expected to acquire an equally important education from both the METI and the university.

Most importantly, however, regardless of the shape it takes, change must be allowed to come about organically from within and must not be enforced upon any institution, and especially not through a liberal-assimilationist or counter-terrorism rationale.

Funding: This research received no external funding.

Acknowledgments: I would like to express my sincere gratitude to Riyaz Timol and Sophie Gilliat-Ray for considering my article for publication, to Haroon Sidat for his feedback and comments, and most of all to my supervisor, Ustadh Yahya Birt, without whose excellent guidance this work could not have been completed.

Conflicts of Interest: The author declares no conflict of interest.

\section{References}

Ali, Mansur. 2018. Muslim Chaplaincy as a Model for Imamship: From Liminality to Immanent Spirituality. In Imams in Western Europe: Developments, Transformations, and Institutional Challenges. Edited by Mohammed Hashas, Jan Jaap De Ruiter and Niels Valdemar Vinding. Amsterdam: Amsterdam University Press, pp. 295-314.

Asad, Talal. 2003. Formations of the Secular: Christianity, Islam, Modernity. Stanford: Stanford University Press.

Bernasek, Lisa, and Gary Bunt. 2008. International Approaches to Islamic Studies in Higher Education: A Report to HEFCE. Ashby: Higher Education Academy.

Bernasek, Lisa, and Gary Bunt. 2010. Islamic Studies Provision in the UK: Report to HEFCE by the Higher Education Academy. Ashby: Higher Education Academy.

Birt, Jonathan. 2006. Good Imam, Bad Imam: Civic Religion and National Integration in Britain Post-9/11. The Muslim World 96: 687-705. [CrossRef]

Birt, Jonathan. 2016. Locating the British Imam: The Deobandi Ulama between Contested Authority and Public Policy Post-9/11. In European Muslims and the Secular State. Edited by Jocelyne Cesari and Seán McLoughlin. Abingdon and Oxon: Routledge, pp. 183-96. 
Birt, Jonathan, and Philip Lewis. 2010. The Pattern of Islamic Reform in Britain: The Deobandis between Intra-Muslim Sectarianism and Engagement with Wider Society. In Producing Islamic Knowledge: Transmission and Dissemination in Western Europe. Edited by Martin Van Bruinessen and Stefano Allievi. London: Routledge, pp. 91-120.

Department for Education and Skills. 2006. Promoting Good Campus Relations: Working with Staff and Students to Build Community Cohesion and Tackle Violent Extremism in The Name of Islam At Universities and Colleges; London: Department for Education and Skills.

Ebbiary, Alyaa. 2018. Re-examining the Decline Narrative: Cambridge Muslim College and the Changing Face of Imam Training in Britain. In Imams in Western Europe: Developments, Transformations, and Institutional Challenges. Edited by Mohammed Hashas, Jan Jaap De Ruiter and Niels Valdemar Vinding. Amsterdam: Amsterdam University Press, pp. 315-36.

Geaves, Ron. 2008. Drawing on the Past to Transform the Present: Contemporary Challenges for Training and Preparing British Imams. Journal of Muslim Minority Affairs 28: 99-112. [CrossRef]

Geaves, Ron. 2013. An Exploration of the Viability of Partnership Between Dar Al-Ulum And Higher Education Institutions in North West England Focusing Upon Pedagogy and Relevance. British Journal of Religious Education 37: 64-82. [CrossRef]

Gilliat-Ray, Sophie, Mansur Ali, and Stephen Pattison. 2013. Understanding Muslim Chaplaincy. London: Routledge. Gilliat-Ray, Sophie. 2005. Closed Worlds: (Not) Accessing Deobandi dar Ul-uloom in Britain. Fieldwork in Religion 1: 7-33. [CrossRef]

Gilliat-Ray, Sophie. 2006. Educating the Ulama: Centres of Islamic Religious Training in Britain. Islam and Christian-Muslim Relations 17: 55-76. [CrossRef]

Gilliat-Ray, Sophie. 2018. From “Closed Worlds" to "Open Doors": (Now) Accessing Deobandi darul Uloom in Britain. Fieldwork in Religion 13: 127-50. [CrossRef]

Higher Education Funding Council for England. 2007. Islamic Studies: Current Status and Future Prospects; Ashby: Lion Court Conference Centre, Higher Education Funding Council for England.

Higher Education Funding Council for England. 2008a. Islamic Studies: The Way Forward in the UK; Ashby: Queen Elizabeth II Conference Centre, Higher Education Funding Council for England.

Higher Education Funding Council for England. 2008b. Islamic Studies: Trends and Profiles; Ashby: Higher Education Funding Council for England.

Hefner, Robert W., and Muhammad Qasim Zaman. 2007. Schooling Islam: The Culture and Politics of Modern Muslim Education. Princeton: Princeton Univ. Press.

Hughes, Aaron W. 2008. Situating Islam: The Past and Future of an Academic Discipline. London: Equinox Pub.

Ingram, Brannon D. 2018. Revival from Below: The Deoband Movement and Global Islam. Oakland: University of California Press.

Larsson, Goran. 2018. Studying Islamic Theology at European Universities. In Imams in Western Europe: Developments, Transformations, and Institutional Challenges. Edited by Mohammed Hashas, Jan Jaap De Ruiter and Niels Valdemar Vinding. Amsterdam: Amsterdam University Press, pp. 121-41.

Lewis, Bernard. 1993. Islam in History: Ideas, People, and Events in the Middle East, 2nd ed.Chicago: Open Court. Lewis, Philip, and Sadek Hamid. 2018. British Muslims: New Directions in Islamic Thought, Creativity and Activism. Edinburgh: Edinburgh University Press.

Liberatore, Giulia. 2019. Guidance as 'Women's Work': A New Generation of Female Islamic Authorities in Britain. Religions 10: 601. [CrossRef]

Mahmood, Hamid. 2012. The Dars-e-Nizāmī and the Transnational Traditionalist Madāris in Britain. Master's thesis, University of London, London, UK.

Mandaville, Peter. 2006. Islamic Education in Britain: Approaches to Religious Knowledge in a Pluralistic Society. In Schooling Islam: The Culture and Politics of Modern Muslim Education. Edited by Robert W. Hefner and Muhammad Qasim Zaman. Princeton: Princeton University Press, pp. 225-41.

Massad, Joseph Andoni. 2016. Islam in Liberalism. Chicago: University of Chicago Press.

Mignolo, Walter D. 2009. Epistemic Disobedience, Independent Thought and Decolonial Freedom. Theory, Culture $\mathcal{E}$ Society 26: 159-81. [CrossRef]

Moosa, Ebrahim. 2015. What is a Madrasa? Chapel Hill: University of North Caroline Press.

Mukadam, Mohamed, and Alison Scott-Baumann. 2010. The Training and Development of Muslim Faith Leaders: Current Practice and Future Possibilities; London: Department for Communities and Local Government. 
Mumisa, Michael. 2014. Quranic Hermeneutics and the British Context. Frankfurter Zeitschrift Für Islamisch-Theologische Studien 1: 82-101.

Petersen, Jesper. 2019. Media and the Female Imam. Religions 10: 159. [CrossRef]

Reetz, Dietrich. 2010. From Madrasa to University: The Challenges and Formats of Islamic Education. In The Sage Handbook of Islamic Studies. Edited by Akbar S. Ahmed and Tamara Sonn. Thousand Oaks: SAGE Publications, pp. 106-39.

Sahin, Abdullah. 2018. Critical Issues in Islamic Education Studies: Rethinking Islamic and Western Liberal Secular Values of Education. Religions 9: 335. [CrossRef]

Sayyid, Salman, and Barnor Hesse. 2006. Narrating the Postcolonial Political and the Immigrant Imaginary. In A Postcolonial People: South Asians in Britain. Edited by Nasreen Ali, Virinder S. Kalra and Salman Sayyid. London: Hurst.

Scott-Baumann, Alison, and Sariya Cheruvallil-Contractor. 2015. Islamic Education in Britain: New Pluralist Paradigms. London: Bloomsbury.

Sidat, Haroon. 2018. Between Tradition and Transition: An Islamic Seminary, or Dar Al-Uloom in Modern Britain. Religions 9: 314. [CrossRef]

Siddiqui, Ataullah. 2007. Islam at Universities in England: Meeting the Needs and Investing in the Future. Islamic Studies 46: 559-70.

Suleiman, Yasir, and Ayman Shihadeh. 2007. Islam on Campus: Teaching Islamic Studies at Higher Education Institutions in the UK. Report of a Conference Held at the University of Edinburgh, 4 December 2006. Journal of Beliefs \& Values 28: 309-29. [CrossRef]

Tyrer, David, and Fauzia Ahmad. 2006. Muslim Women and Higher Education: Identities, Experiences and Prospects. Liverpool: Liverpool John Moore University and European Social Fund.

Wehr, Hans, and J. Milton Cowan. 1993. A Dictionary of Modern Written Arabic: (Arabic - English). Urbana: Spoken Language Services.

Zaman, Muhammad Qasim. 2007. The Ulama in Contemporary Islam: Custodians of Change. Princeton: Princeton University Press.

(C) 2019 by the author. Licensee MDPI, Basel, Switzerland. This article is an open access article distributed under the terms and conditions of the Creative Commons Attribution (CC BY) license (http://creativecommons.org/licenses/by/4.0/). 